\title{
Environmental sex determination in a parasitic copepod: checking heterogeneity and unpredictability of the environment
}

\author{
Marilyn Michaud ${ }^{1,2, *}$, Thierry de Meeûs ${ }^{1}$, François Renaud ${ }^{1}$ \\ ${ }^{1}$ Centre d'Etude sur le Polymorphisme des Micro-Organismes, Centre IRD de Montpellier, CEPM/UMR CNRS-IRD 9926, \\ Equipe 'Evolution des Systèmes Symbiotiques', 911 Avenue Agropolis, BP 5045, 34032 Montpellier Cedex 1, France \\ ${ }^{2}$ Station Méditerranéenne de l'Environnement Littoral, (SMEL, Université Montpellier II), 1, quai de la daurade, \\ 34200 Sète, France
}

\begin{abstract}
For some organisms, sex is not fixed by genotype at conception but determined later by environmental conditions encountered during development (environmental sex determination, ESD). According to theoretical models, selection should favour ESD when the environment experienced by offspring is patchy and unpredictable and affects the relative fitness of males and females differentially. In a field study, we analysed the environmental heterogeneity displayed among individuals of the sea squirt Ciona intestinalis, a host for the copepod Pachypygus gibber, which is characterised by ESD. Consistent with theoretical predictions, environmental parameters that affect sex-specifically the fitness of the parasite (food and sexual partners) vary significantly in space and time. The spatial genetic structure of populations of $P$. gibber in the Thau lagoon, France, was investigated from allozyme data. No differentiation was found between distant populations, indicating that the larvae disperse intensively in the lagoon. Since their environment has been shown to be heterogeneous in space, and since the mothers cannot leave the host in which they developed, we conclude that both parent and offspring have little control over the quality of the environment the offspring enters. All the conditions are thus validated to support the adaptive nature of ESD in P. gibber.
\end{abstract}

KEY WORDS: Sex-determining mechanism $\cdot$ Selection $\cdot$ Heterogeneity $\cdot$ Unpredictability $\cdot$ Parasite Copepod $\cdot$ Pachypygus gibber

Resale or republication not permitted without written consent of the publisher

\section{INTRODUCTION}

Among dioecious species 2 major sex-determining mechanisms can be distinguished: genotypic sex determination (GSD) groups mechanisms in which an individual's sex depends largely on its genotype. In environmental sex determination (ESD), an individual's sex is determined after conception largely in response to the larval or embryonic environment (reviewed in Bull 1983 and Adams et al. 1987). The origin of ESD has been discussed from 2 points of view, which are actually not incompatible. Some authors proposed that ESD may be the primitive sexdetermining mechanism (Ohno 1967, Mittwoch 1971,
Jones 1983), from which ancestral state a genetic system of control (followed by sex chromosomes) would have evolved. Others (Bacci 1965, Charnov \& Bull 1977) have supposed that ESD is adaptive in certain life histories by allowing control of sex in response to environmental effects on fitness. Theoretical studies (Charnov 1979, Bull 1981, Bulmer \& Bull 1982) have supported the hypothesis that ESD is favoured in such life histories.

The facultative sex ratio is the alteration of production of sons or daughters in response to particular environmental conditions. Trivers \& Willard (1973) developed a natural selection approach to facultative sex ratios based on a theoretical population of mam- 
mals. However, their key idea can be generalised to hermaphrodites and to many other sex-ratio systems: '[t]he allocation of resources to male versus female function should be sensitive and respond to the relative gain possible through either sex function' (Charnov 1982). Based on the sex-ratio argument of Trivers \& Willard (1973), Charnov \& Bull (1977) proposed that ESD might be superior to GSD under particular conditions. Specifically, ESD should be strongly favoured by natural selection in a species when (1) fitness is strongly and sex-specifically influenced by environmental conditions, (2) these environmental conditions are heterogeneous (i.e. patchy), and (3) parents and offspring have little control or predictive ability over what patch quality the descendant will experience. Therefore, a basic prediction of this model is that species with ESD will have life histories consistent with these requirements.

On the Mediterranean French coasts, the copepod Pachypygus gibber (Thorell, 1859) is a parasite of the sea squirt Ciona intestinalis (L.). The host uses the ciliated surface of its branchial cavity to filter water and concentrate particles in suspension into a dense food mass (called cordon). The copepod feeds directly on this food cordon before it enters the oesophagus of the host to be digested (kleptoparasitism). ESD has been demonstrated in P. gibber and postulated to be adaptive (Becheikh et al. 1998). The goal of the present study was to test for the existence of all the conditions of the Charnov-Bull theoretical model in this copepod species.

The life cycle of Pachypygus gibber can be summarised as follows: females lay eggs in the host in which they developed and mated. After hatching, the larvae (nauplii 1 to 6 and copepodid 1 stages) lead a planktonic existence and develop using their yolk reserve. The infective stage (copepodid 2) enters a host, and thereafter parasitic life becomes obligatory. After 4 successive moults, it develops into 1 of 3 adult stages: a female, a typical male or an atypical male. These 3 sexual phenotypes, well described by Hipeau-Jacquotte $(1978,1980)$, have different sizes and development times: females (length 3.5 to $8 \mathrm{~mm}$ ) are larger than typical males (1.6 to $2.5 \mathrm{~mm}$ ), and typical males are larger than atypical ones ( 0.76 to $1 \mathrm{~mm}$ ). Development time depends on body size, being longer for females than for typical males, and longer for typical males than for atypical ones (Becheikh 1996). This supports the hypothesis of a differential cost in the production of a male (atypical or typical) or a female. In addition, females and typical males are unable to leave the host, whereas atypical males swim outside of the host and have mouthparts adapted to feeding in water (HipeauJacquotte 1980) and are attracted by females (Michaud et al. 1999). These abilities allow atypical males to seek and fertilise a female in another host than the one in which they developed. Females produce successive clutches, and typical males regenerate spermatophores after mating. In contrast, atypical males can reproduce only once, since they die after the extrusion of their spermatophores, due to the disruption of the genital segment (Hipeau-Jacquotte \& Coste 1989). Becheikh et al. (1998) showed that these 3 sexual phenotypes are environmentally determined depending on the availability of food and/or sexual partners. All these observations indicate that condition (1) of the Charnov-Bull model is fullfilled by $P$. gibber (see 'Discussion').

In order to test for condition (2), we investigated environmental heterogeneity experienced by Pachypygus gibber in the Thau lagoon, France. The relevant parameters to be studied in host populations have to be essential for parasite fitness. We thus considered host size, parasite presence, parasite abundance (total numbers and numbers of adult parasites) and parasite sex ratio as relevant indicators of the environmental conditions experienced by the parasite's immature stages. We estimated these parameters in natural populations and tested how variable they were in space and time.

Since a heterogeneous environment can be nevertheless predictable, we investigated environmental unpredictability, by studying the population genetic structure of Pachypygus gibber in the Thau lagoon, to test for condition (3). Nauplii are released from the host which harbours their mother and spread in water streams, where they develop until they reach the infective stage. To assess whether these larvae mate far away from their mothers, we tested the genetic differentiation of $P$. gibber between the different studied sites in the Thau lagoon. Absence of spatial differentiation, hence large-distance dispersal among heterogeneous environments, would suggest that $P$. gibber cannot predict the environmental conditions of its offspring.

All these results are discussed in the context of ESD versus GSD, and in the light of our knowledge on the copepod Pachypygus gibber.

\section{MATERIALS AND METHODS}

Data collection. Environmental heterogeneity: Samples of Ciona intestinalis were collected from February 1997 to June 1999 at 3 geographical sites in the Thau lagoon, France ( $\left.43^{\circ} 25^{\prime} \mathrm{N}, 3^{\circ} 35^{\prime} \mathrm{E}\right)$. The distances between sites were $4 \mathrm{~km}$ (between Sites 1 and 2), $8.6 \mathrm{~km}$ (between Sites 2 and 3) and $11.3 \mathrm{~km}$ (between Sites 1 and 3). The number of sea squirts collected for each site and date are reported in Table 1. All samples were collected at 3 to $4 \mathrm{~m}$ depth. 
Table 1. Number of sea squirts collected per sample. na: sampling data not available for the site on this date. 0: sea squirts were absent at the sampling site on this date

\begin{tabular}{|lrrrrr|}
\hline Month & Year & Site 1 & Site 2 & Site 3 & Total \\
\hline Feb & 1997 & 100 & 31 & 0 & 131 \\
Mar & 1997 & 114 & 0 & 0 & 114 \\
May & 1997 & 0 & 131 & 0 & 131 \\
Jun & 1997 & 40 & 28 & 0 & 68 \\
Jul & 1997 & 97 & 29 & 48 & 174 \\
Dec & 1997 & 30 & 89 & 117 & 236 \\
Jul & 1998 & 149 & 236 & 100 & 485 \\
Jan & 1999 & 200 & 115 & na & 315 \\
Feb & 1999 & 72 & na & na & 72 \\
Apr & 1999 & 280 & na & na & 280 \\
Jun & 1999 & 61 & 55 & na & 116 \\
Total & & 1143 & 714 & 265 & 2122 \\
\hline
\end{tabular}

Sea squirts sampled in the Thau lagoon were transferred alive to the biological laboratory of the SMEL (Station Méditerranéenne de l'Environnement Littoral, University Montpellier II, Sète, France), which is located on the shores of the lagoon. Host size was estimated by measuring host length to the nearest $\mathrm{mm}$. Sea squirts were dissected in order to count adult and juvenile copepods that they harboured. We thereby estimated the presence, abundance, and sex ratio of the parasite. Parasite presence indicates whether the host is unparasitised (0) or parasitised (1). Abundance is the number of parasites per examined host (Margolis et al. 1982, Bush et al. 1997). The sex ratio represents the number of males as a proportion of the total number of adults. Since no atypical males were found in this sample, the sex ratio was calculated as the ratio between typical males and females.

Differentiation between populations (genetic characterisation): Sea squirts at the 3 sites were sampled twice within a short time period (late December 1997 to early January 1998). Copepods were removed from sea squirts immediately after sampling. Females (adult and copepodid 5 stages) and typical males were stored in individual tubes at $-80^{\circ} \mathrm{C}$. Other stages were too small to provide sufficient quantities of enzyme to allow reading of gels. Electrophoresis was carried out using $10 \%$ starch gels following the method described in Pasteur et al. (1987). Whole frozen copepods were crushed directly on $2 \times 10 \mathrm{~mm}$ Whatman No. 5 filter papers. Thirty-four enzyme systems were tested using 6 different buffers, and 12 putative loci were correctly interpretable: acid-phosphatase (ACP; E.C. 3.1.3.2), creatine-kinase (CK; E.C. 2.7.3.2), glucose-phosphateisomerase (GPI; E.C. 5.3.1.9), malate-dehydrogenase

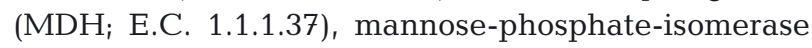

(MPI; E.C. 5.3.1.9), peptidases (PEP A, substrate ValLeu, 2 loci noted PEP-Val and PEP-Leu; PEP B, substrate Leu-Gly-Gly, 2 loci noted PEP-Leu and PEP-Gly; PEP C, substrate Lys-Leu; and PEP E, substrate PhePro; E.C. 3.4.11), 6-phosphogluconic-dehydrogenase (6-PGD; E.C. 1.1.1.44), and phospho-gluco-mutase (PGM; E.C. 2.7.5.1, 2 loci noted PGM1 and PGM2). Among those loci, 5 appeared polymorphic, with 2 alleles each: MPI, PEP-Gly, PEP-Leu, PEP E and PGM2. For Sites 1, 2 and 3, we characterised 36 to 79 , 9 to 20 and 17 to 35 individuals, respectively, depending on the locus.

Occurrence of atypical males: At Site 1, an artificial substrate (15 plastic quadrats, size $7.5 \times 7.5 \mathrm{~cm}$, along a $4 \mathrm{~m}$ rope) was used to recruit young larvae of Ciona intestinalis ( $\mathrm{S}$. Becheikh unpubl. data). In November and December 1994, the sea squirts were measured and dissected. Juvenile and adult stages of Pachypygus gibber were determined and counted.

At Sites 1, 2 and 3, in May and June 1997, the same design was used, except that the artificial substrate was collected together with the water volume contained by the sampling plastic bag. The water was then filtered $(250 \mu \mathrm{m})$ to catch atypical males which could have escaped from hosts.

Data analysis. Environmental heterogeneity: The following variables were considered: 'site' (geographical localisation), 'HostSize' (host size), 'PP' (parasite presence), 'Ab' (abundance [juvenile and adult stages]), 'AdNb' (adult abundance [number of adults]) and 'SexRatio' (parasite sex ratio). We built a variable 'month', grouping all data sampled in the same month, and a variable 'year', grouping all data sampled in the same year.

The data were analysed by generalised linear modelling using S-Plus 2000 (MathSoft 2000). As used in previous studies (e.g. Dawson et al. 2000), binomial error was used for binary or proportional (with weights) data, Poisson error for counts and Gaussian error for continuous data. However, when data were over-dispersed, quasi-likelihood estimation, with the appropriate link and variance functions, was used as recommended (MathSoft 2000). The initial models included all variables and all interactions (noted with a colon) that could be tested (depending on sample size and singularities). The models were then simplified by a backward stepwise process following the Akaike information criterion (AIC) (MathSoft 2000). The minimal models produced include variables and interactions that were significant, but also variables that were involved in a significant interaction, although they were sometimes not significant alone. Since 5 models were built with the same data set, we decreased the significance level to $1 \%$ instead of $5 \%$. 
Differentiation between populations: The genetic structure of the populations was analysed using Wright's Fst (Wright 1951, 1965), which measures the genetic differentiation between the different samples. Its value ranges from 0 (random distribution of individuals) to 1 (1 nuclear allele fixed at each locus, in one or the other sample). This parameter was estimated by the Weir \& Cockerham (1984) unbiased estimator $\theta$, which was computed with the program Fstat V 2.9.3.2 (updated in 2002 from Goudet 1995). This program also performs permutation procedures that we used to test the departure from 0 of the estimator $\theta$. After a sufficient number of re-samplings of the data $(n=15000)$, a distribution of the different possible values under the null hypothesis is obtained for the estimator. The comparison of the observed value to this distribution provides an unbiased estimate of the exact probability of obtaining by chance a value as large as or larger than the one observed (type-I error). The tests were thus 1-tailed. Population structuring was tested by permuting individuals between sites. The tests were carried out for each pair of sites and over the 3 sites, using the 5 polymorphic loci.

\section{RESULTS}

\section{Descriptive data}

For each variable, descriptive statistics (minimum, maximum, mean, standard deviation and confidence limits of the mean) are given in Tables 2 to 5 .

\section{Environmental heterogeneity}

The initial model for HostSize was ( $\mathrm{N}=1218)$ :

HostSize $\approx$ site + month + year + site:month + site:year

The backward selection process did not simplify this model $\left(R^{2}=0.19\right)$. The terms month, site:month and site:year were highly significant $(\mathrm{p}<0.001)$, site was significant $(p<0.01)$ and year was not significant $(\mathrm{p}>0.01)$. Since HostSize was used as an explanatory variable together with site, month and year in other models, the residuals of this model (ResHSize) were kept for further analyses. This prevents problems of colinearity between explanatory variables.

The initial model to study PP was $(\mathrm{N}=1218)$ :

$\mathrm{PP} \approx$ site + month + year + ResHSize + site:month + site:year + month:year + site:ResHSize + month:ResHSize + year:ResHSize + site:month:year + site:month: ResHSize + site:year:ResHSize + month:year:ResHSize + site:month:year:ResHSize
The minimal model was:

$\mathrm{PP} \approx$ site + month + year + ResHSize + site:month + site:year + site:ResHSize + month:ResHSize + year: ResHSize + site:year:ResHSize $\left(\mathrm{R}^{2}=0.35\right)$

The terms month, year, ResHSize and site:month were highly significant ( $p<0.001)$, the term month: ResHSize was significant $(p<0.01)$ and the 5 other terms were not significant $(p>0.01)$.

The initial model for Ab was $(\mathrm{N}=1218)$ :

$\mathrm{Ab} \approx$ site + month + year + ResHSize + site:month + site:year + site:ResHSize + month:ResHSize + year:

ResHSize + site:month:ResHSize + site:year:ResHSize

Since over-dispersion was strong $(\phi=4.91)$, a quasilikelihood estimation was used. The minimal model was:

$\mathrm{Ab} \approx$ site + month + year + ResHSize + site:month + site:year + site:ResHSize + year:ResHSize + site:year:

ResHSize $\left(\mathrm{R}^{2}=0.47\right)$

The terms month, year, ResHSize, site:month and site:ResHSize were highly significant $(p<0.001)$, the term year:ResHSize was significant $(\mathrm{p}<0.01)$ and the 3 other terms were not significant ( $p>0.01$ ).

For AdNb (adult abundance) the initial model was $(\mathrm{N}=733)$ :

$\mathrm{AdNb} \approx$ site + month + year + ResHSize + site:month + site:ResHSize + month:ResHSize + year:ResHSize + site:month: ResHSize

Because data were over-dispersed ( $\phi=1.6)$, a quasilikelihood estimation was used. The minimal model was:

$\mathrm{AdNb} \approx$ site + month + year + ResHSize + site:month + site:ResHSize + month:ResHSize + year:ResHize $\left(\mathrm{R}^{2}=0.46\right)$

The terms site, month, ResHSize and site:month were highly significant ( $p<0.001)$, the term month: ResHSize was significant $(p<0.01)$ and the 3 other terms were not significant $(p>0.01)$.

To use properly AdNb as an explanatory variable in the model explaining SexRatio, the residuals of the minimal model (i.e. ResAdNb) were kept.

The model for SexRatio (proportional data) involves the number of adults (i.e. AdNb) as a weight. The initial model was $(\mathrm{N}=271)$ :

SexRatio $\approx$ site + month + year + ResHSize + ResAdNb + site:month + site:ResHSize + ResAdNb + month: ResHSize + month:ResAdNb + year:ResHSize + year: ResAdNb + site:month:ResHSize + site:month:ResAdNb

The minimal model was:

SexRatio $\approx$ site + month + year + ResHSize + ResAdNb + site:month + site:ResHSize + site:ResAdNb + month: $\operatorname{ResAdNb}\left(\mathrm{R}^{2}=0.23\right)$

Only the effect of ResAdNb was highly significant $(p<0.001)$. Year and site:month were significant $(p<$ 0.01). The 6 remaining terms were not significant, despite their importance in the minimal model. 
Table 2. Overall descriptive statistics. Variables are defined in 'Materials and methods: Data collection'

\begin{tabular}{|lccccc|}
\hline & $\begin{array}{c}\text { Host size } \\
\text { (HostSize) }\end{array}$ & $\begin{array}{c}\text { Parasite presence } \\
\text { (PP) }\end{array}$ & $\begin{array}{c}\text { Abundance } \\
\text { (Ab) }\end{array}$ & $\begin{array}{c}\text { Adult number } \\
\text { (AdNb) }\end{array}$ & $\begin{array}{c}\text { Sex ratio } \\
\text { (SexRatio) }\end{array}$ \\
\hline Min-max & $2-160$ & $0-1$ & $0-81$ & $0-20$ & $0-1$ \\
Mean (SD) & $47.1(24.4)$ & $0.44(0.49)$ & $1.79(4.56)$ & $0.65(1.54)$ & $0.28(0.36)$ \\
CL of the mean & $45.7-48.5$ & $0.42-0.46$ & $1.60-1.98$ & $0.58-0.73$ & $0.25-0.31$ \\
\hline
\end{tabular}

Table 3. Descriptive statistics for Site 1. Variables are defined in 'Materials and methods'. na: data are not available on this sampling date, either because sea squirts were absent or because the variable could not be measured (see Table 1). Data are presented as means (SD)

\begin{tabular}{|c|c|c|c|c|c|c|c|c|c|c|c|}
\hline & $\begin{array}{l}\text { Feb } \\
1997\end{array}$ & $\begin{array}{l}\text { Mar } \\
1997\end{array}$ & $\begin{array}{l}\text { May } \\
1997\end{array}$ & $\begin{array}{l}\text { Jun } \\
1997\end{array}$ & $\begin{array}{c}\text { Jul } \\
1997\end{array}$ & $\begin{array}{l}\text { Dec } \\
1997\end{array}$ & $\begin{array}{c}\text { Jul } \\
1998\end{array}$ & $\begin{array}{c}\text { Jan } \\
1999\end{array}$ & $\begin{array}{l}\text { Feb } \\
1999\end{array}$ & $\begin{array}{l}\text { Apr } \\
1999\end{array}$ & $\begin{array}{l}\text { Jun } \\
1999\end{array}$ \\
\hline $\begin{array}{l}\text { Host size } \\
\text { (HostSize) }\end{array}$ & $\begin{array}{c}29 \\
(20.7)\end{array}$ & $\begin{array}{l}35.8 \\
(20.9)\end{array}$ & na & $\begin{array}{c}48.1 \\
(23.7)\end{array}$ & $\begin{array}{l}46.8 \\
(23)\end{array}$ & na & $\begin{array}{c}57.7 \\
(20.5)\end{array}$ & na & na & na & $\begin{array}{c}58.1 \\
(24.6)\end{array}$ \\
\hline $\begin{array}{l}\text { Parasite } \\
\text { presence (PP) }\end{array}$ & $\begin{array}{c}0.37 \\
(0.48)\end{array}$ & $\begin{array}{c}0.20 \\
(0.40)\end{array}$ & na & $\begin{array}{c}0.65 \\
(0.48)\end{array}$ & $\begin{array}{c}0.60 \\
(0.49)\end{array}$ & $\begin{array}{c}0.93 \\
(0.25)\end{array}$ & $\begin{array}{c}0.88 \\
(0.31)\end{array}$ & $\begin{array}{c}0.13 \\
(0.33)\end{array}$ & $\begin{array}{c}0.18 \\
(0.38)\end{array}$ & $\begin{array}{c}0.18 \\
(0.38)\end{array}$ & $\begin{array}{c}0.80 \\
(0.40)\end{array}$ \\
\hline $\begin{array}{l}\text { Abundance } \\
\text { (Ab) }\end{array}$ & $\begin{array}{c}0.77 \\
(1.60)\end{array}$ & $\begin{array}{c}0.30 \\
(0.74)\end{array}$ & na & $\begin{array}{c}2.42 \\
(2.73)\end{array}$ & $\begin{array}{c}1.79 \\
(2.62)\end{array}$ & $\begin{array}{c}6.56 \\
(5.74)\end{array}$ & $\begin{array}{c}8.16 \\
(10.47)\end{array}$ & $\begin{array}{c}0.13 \\
(0.35)\end{array}$ & $\begin{array}{c}0.18 \\
(0.38)\end{array}$ & $\begin{array}{c}0.32 \\
(0.83)\end{array}$ & $\begin{array}{c}2.19 \\
(1.99)\end{array}$ \\
\hline $\begin{array}{l}\text { Adult number } \\
\text { (AdNb) }\end{array}$ & $\begin{array}{c}0.73 \\
(1.56)\end{array}$ & $\begin{array}{c}0.30 \\
(0.74)\end{array}$ & na & $\begin{array}{c}1.92 \\
(2.41)\end{array}$ & $\begin{array}{l}1.47 \\
(2.23)\end{array}$ & $\begin{array}{c}5.13 \\
(4.57)\end{array}$ & na & $\begin{array}{c}0.13 \\
(0.35)\end{array}$ & $\begin{array}{c}0.18 \\
(0.38)\end{array}$ & $\begin{array}{c}0.26 \\
(0.77)\end{array}$ & $\begin{array}{c}1.63 \\
(1.56)\end{array}$ \\
\hline $\begin{array}{l}\text { Sex ratio } \\
\text { (SexRatio) }\end{array}$ & $\begin{array}{c}0.27 \\
(0.35)\end{array}$ & $\begin{array}{c}0.27 \\
(0.40)\end{array}$ & na & $\begin{array}{c}0.44 \\
(0.31)\end{array}$ & $\begin{array}{c}0.35 \\
(0.38)\end{array}$ & $\begin{array}{c}0.50 \\
(0.28)\end{array}$ & na & $\begin{array}{c}0.01 \\
(0.09)\end{array}$ & $\begin{array}{c}0.07 \\
(0.27)\end{array}$ & $\begin{array}{c}0.44 \\
(0.40)\end{array}$ & $\begin{array}{c}0.30 \\
(0.31)\end{array}$ \\
\hline
\end{tabular}

Table 4. Descriptive statistics for Site 2. Details as in Table 3

\begin{tabular}{|c|c|c|c|c|c|c|c|c|c|c|c|}
\hline & $\begin{array}{l}\text { Feb } \\
1997\end{array}$ & $\begin{array}{l}\text { Mar } \\
1997\end{array}$ & $\begin{array}{l}\text { May } \\
1997\end{array}$ & $\begin{array}{l}\text { Jun } \\
1997\end{array}$ & $\begin{array}{c}\text { Jul } \\
1997\end{array}$ & $\begin{array}{l}\text { Dec } \\
1997\end{array}$ & $\begin{array}{c}\text { Jul } \\
1998\end{array}$ & $\begin{array}{l}\text { Jan } \\
1999\end{array}$ & $\begin{array}{l}\text { Feb } \\
1999\end{array}$ & $\begin{array}{l}\text { Apr } \\
1999\end{array}$ & $\begin{array}{l}\text { Jun } \\
1999\end{array}$ \\
\hline $\begin{array}{l}\text { Host size } \\
\text { (HostSize) }\end{array}$ & $\begin{array}{c}57.5 \\
(15.4)\end{array}$ & na & $\begin{array}{c}36.4 \\
(18.8)\end{array}$ & $\begin{array}{c}46.9 \\
(15.8)\end{array}$ & $\begin{array}{c}44 \\
(23.9)\end{array}$ & na & $\begin{array}{c}57.9 \\
(26.8)\end{array}$ & na & na & na & $\begin{array}{l}43.6 \\
(22)\end{array}$ \\
\hline $\begin{array}{l}\text { Parasite } \\
\text { presence (PP) }\end{array}$ & $\begin{array}{c}0.77 \\
(0.42)\end{array}$ & na & $\begin{array}{c}0.16 \\
(0.36)\end{array}$ & 0 & $\begin{array}{c}0.51 \\
(0.50)\end{array}$ & $\begin{array}{c}0.61 \\
(0.48)\end{array}$ & $\begin{array}{c}0.79 \\
(0.40)\end{array}$ & $\begin{array}{c}0.19 \\
(0.39)\end{array}$ & na & na & $\begin{array}{c}0.21 \\
(0.41)\end{array}$ \\
\hline $\begin{array}{l}\text { Abundance } \\
\text { (Ab) }\end{array}$ & $\begin{array}{c}3.67 \\
(3.60)\end{array}$ & na & $\begin{array}{c}0.19 \\
(0.48)\end{array}$ & 0 & $\begin{array}{c}0.82 \\
(1.07)\end{array}$ & $\begin{array}{c}0.97 \\
(1.07)\end{array}$ & $\begin{array}{c}4.37 \\
(6.29)\end{array}$ & $\begin{array}{c}0.21 \\
(0.52)\end{array}$ & na & na & $\begin{array}{c}0.21 \\
(0.41)\end{array}$ \\
\hline $\begin{array}{l}\text { Adult number } \\
\text { (AdNb) }\end{array}$ & $\begin{array}{c}3.67 \\
(3.60)\end{array}$ & na & $\begin{array}{c}0.18 \\
(0.44)\end{array}$ & 0 & $\begin{array}{c}0.75 \\
(0.98)\end{array}$ & $\begin{array}{c}0.88 \\
(0.99)\end{array}$ & na & $\begin{array}{c}0.21 \\
(0.52)\end{array}$ & na & na & $\begin{array}{c}0.20 \\
(0.40)\end{array}$ \\
\hline $\begin{array}{l}\text { Sex ratio } \\
\text { (SexRatio) }\end{array}$ & $\begin{array}{c}0.55 \\
(0.33)\end{array}$ & na & $\begin{array}{c}0.50 \\
(0.47)\end{array}$ & na & $\begin{array}{c}0.25 \\
(0.38)\end{array}$ & $\begin{array}{c}0.13 \\
(0.26)\end{array}$ & na & $\begin{array}{c}0.07 \\
(0.26)\end{array}$ & na & na & 0 \\
\hline
\end{tabular}

Table 5. Descriptive statistics for Site 3. Details as in Table 3

\begin{tabular}{|c|c|c|c|c|c|c|c|c|c|c|c|}
\hline & $\begin{array}{l}\text { Feb } \\
1997\end{array}$ & $\begin{array}{l}\text { Mar } \\
1997\end{array}$ & $\begin{array}{l}\text { May } \\
1997\end{array}$ & $\begin{array}{l}\text { Jun } \\
1997\end{array}$ & $\begin{array}{c}\text { Jul } \\
1997\end{array}$ & $\begin{array}{l}\text { Dec } \\
1997\end{array}$ & $\begin{array}{c}\text { Jul } \\
1998\end{array}$ & $\begin{array}{c}\text { Jan } \\
1999\end{array}$ & $\begin{array}{l}\text { Feb } \\
1999\end{array}$ & $\begin{array}{l}\text { Apr } \\
1999\end{array}$ & $\begin{array}{l}\text { Jun } \\
1999\end{array}$ \\
\hline $\begin{array}{l}\text { Host size } \\
\text { (HostSize) }\end{array}$ & na & na & na & na & $\begin{array}{c}64 \\
(23.1)\end{array}$ & na & $\begin{array}{c}35.8 \\
(15.3)\end{array}$ & na & na & na & na \\
\hline $\begin{array}{l}\text { Parasite } \\
\text { presence (PP) }\end{array}$ & na & na & na & na & $\begin{array}{c}0.41 \\
(0.49)\end{array}$ & $\begin{array}{c}0.58 \\
(0.49)\end{array}$ & $\begin{array}{c}0.69 \\
(0.46)\end{array}$ & na & na & na & na \\
\hline $\begin{array}{l}\text { Abundance } \\
\text { (Ab) }\end{array}$ & na & na & na & na & $\begin{array}{c}0.66 \\
(1.01)\end{array}$ & $\begin{array}{c}0.88 \\
(0.96)\end{array}$ & $\begin{array}{c}2.93 \\
(6.16)\end{array}$ & na & na & na & na \\
\hline $\begin{array}{l}\text { Adult number } \\
\text { (AdNb) }\end{array}$ & na & na & na & na & $\begin{array}{c}0.37 \\
(0.63)\end{array}$ & $\begin{array}{c}0.70 \\
(0.87)\end{array}$ & na & na & na & na & na \\
\hline $\begin{array}{l}\text { Sex ratio } \\
\text { (SexRatio) }\end{array}$ & na & na & na & na & $\begin{array}{c}0.28 \\
(0.46)\end{array}$ & $\begin{array}{c}0.20 \\
(0.32)\end{array}$ & na & na & na & na & na \\
\hline
\end{tabular}




\section{Differentiation between populations}

No significant differentiation between populations was found. For the closest sites (Sites 1 and 2, separated by $4 \mathrm{~km}), \theta=0.063, \mathrm{p}=0.109$; for Sites 2 and 3 (separated by $8.6 \mathrm{~km}$ ), $\theta=0.027, \mathrm{p}=0.199$; and for the most distant sites (Sites 1 and 3, separated by $11.3 \mathrm{~km}$ ), $\theta=-0.002, p=0.255$. Over all loci and all sites, $\theta=$ $0.026, \mathrm{p}=0.282$.

\section{Occurrence of atypical males}

November-December 1994

The size (length) of the sea squirts ranged from 1.5 to $5 \mathrm{~mm}$. Among the 1190 sea squirts dissected, only atypical stages were found. The prevalence of atypical stages (from copepodid 4 to adult stage) was $7.9 \%$, and their mean abundance was 0.07 .

$$
\text { May-July } 1997
$$

Only 1 atypical male was found in $160 \mathrm{l}$ of filtered water. The size (length) of the sea squirts ranged from 2 to $25 \mathrm{~mm}$. Among the 2007 sea squirts dissected, $0.39 \%$ were infected with atypical stages (juvenile or adult atypical stages). Among all copepods obtained, the proportion of atypical stages was $0.9 \%(8 / 849)$.

\section{DISCUSSION}

\section{Environmental heterogeneity}

Host size was shown to vary significantly in time (month) and space (site). Host size can be viewed as an estimator of host quality, because it can be expected that the bigger a sea squirt, the higher its capacity to filter water. Big hosts should thus provide more nutrients (i.e. algae). Consequently, variation in host size in the Thau lagoon indicates that growing conditions (i.e. food availability) encountered by the infective stage of Pachypygus gibber are patchy.

Parasite presence and abundance vary both in time (month and year) and with host size. Even though site is not significant alone, it is involved in significant interactions (with month and host size). Adult abundance varies significantly in time (month) and space (site), and with host size. Parasite presence reflects the probability that a copepodid will enter a previously infected host, and thereby encounter an individual of the same species. Parasite abundance and adult number are correlated with intraspecific competition for food and sexual partner(s) within a host. Thus, both growing and sex-differentiation conditions met by an infective copepodid during its development are patchy.

The sex ratio is mainly explained by adult abundance, the proportion of males increasing with the number of adults harboured by the host. Increasing competition for food may explain this result. Development into a female may be too costly at a high parasitic load. Parasite sex ratio varies also in time (year) and even though site is not significant alone, it is involved in a significant interaction with month. The fact that the sex of a juvenile in Pachypygus gibber develops in response to the sex of the adult present in the environment (Becheikh et al. 1998) implies that sexdifferentiation conditions are patchy. We thus conclude that condition (2) of the Charnov-Bull model can be validated in $P$. gibber.

\section{Environmental unpredictability}

The fact that an environment is heterogeneous does not necessarily imply that it is unpredictable. In the case of heterogeneity in space, organisms may control the environmental conditions of development by choosing the site of settlement (offspring) or of egglaying (parent). In the case of heterogeneity in time, variations can be predictable if they occur regularly or if natural indicators of change can be monitored by organisms.

From the present study no significant genetic differentiation was revealed between the 3 sites in the Thau lagoon. This indicates that substantial gene exchange occurs between distant sites (from 4 to $11.3 \mathrm{~km}$ ). But we cannot discriminate the gene flow due to larval dispersal from one due to the swimming behaviour of atypical males. Nevertheless, our results (see 'Results: Occurrence of atypical males') indicate that in populations of very young larvae of Ciona intestinalis (November-December 1994), where only atypical development is possible (length up to $5 \mathrm{~mm}$ ), abundance of atypical stages is low, and that, in populations of bigger hosts (May-July 1997), typical stages are largely more represented than atypical ones $(99.1 \%)$. Moreover, atypical males can mate only once (HipeauJacquotte \& Coste 1989), while typical males and females can produce successive spermatophores and clutches, respectively. Consequently, the contribution of atypical males is not expected to be very significant.

The strong dispersal of larvae before they infect a new host means that larvae hatch at one site, but are infective only later on at another site. Host size, adult abundance and sex ratio have been shown to vary significantly among sites, and these parameters reflect 
conditions of development, which are essential for the parasite's fitness (i.e. food and sexual partners). So the females, which are 'prisoner' of the host where they developed, cannot predict the environment where their offspring will develop. A fortiori males cannot predict the offspring development conditions either, since their contribution is limited to the fertilisation of females.

Moreover, the larvae themselves cannot predict the environment where they will develop. Indeed, in Pachypygus gibber, larvae which attain the infective stage (i.e. copepodid 2) have to find a host to develop further and reach the adult stage. It has been shown experimentally that copepodid 2 individuals are always attracted by hosts when they have the choice between hosts and anything else (seawater and/or sexual partners), and that they cannot detect a female present in a host (Michaud et al. 1999). Thus, copepodid 2 individuals cannot predict which mating type they will encounter.

We can conclude that condition (3) of the CharnovBull model applies to Pachypygus gibber: '[t]he offspring and parent have little control (or predictive ability) over which patch type the offspring enters' (Charnov \& Bull 1977).

\section{Conclusion}

The first condition of the Charnov-Bull model was known to be fullfilled in the parasitic copepod Pachypygus gibber: food resources and sexual partners affect individual fitness strongly and sexspecifically.

The 3 sexual phenotypes of Pachypygus gibber are environmentally determined depending on the availability of food resources and of sexual partners (Becheikh et al. 1998). The results of that study can be summarised as follows:

- A copepodid 2 growing in poor, intermediate or rich trophic conditions (i.e. algae concentration) develops, respectively, into an atypical male, a typical male or a female.

- A copepodid 2 growing in intermediate algae concentration with a typical male develops either into a female or (less often) into an atypical male, rarely developing into a typical male.

- A copepodid 2 growing in high algae concentration with a female develops into a typical male.

Differences in body size and development time between the 3 adult phenotypes indicate a differential cost in the production of these phenotypes. Both parameters, availability of food resources and of potential sexual partners, appear to affect individual fitness strongly and sex-specifically: a larva that encounters a poor environment (e.g. a small host or a host occurring at a site that provides few nutrients) should gain more benefit by developing into an atypical male, because its development is less costly than if it develops into a typical male. Furthermore, once it reaches the adult stage, it can escape the poor environment to find and fertilise a female in another host. In contrast, a larva which enters a rich environment should gain more benefit by developing into a typical phenotype (male or female), since this development, although it is more costly in time and food resources, enables more than one single mating. Furthermore, if we consider now a host already harbouring one adult-stage individual, a larva which encounters a female should gain more benefit by developing into a typical male, thereby ensuring at least one copulation, while a larva which encounters a typical male should gain more benefit by developing into a female, or into an atypical male if the food resources are too low.

The 2 other conditions of the model are validated by the results of the present study. The availability of food resources and sexual partners for an infective stage is heterogeneous in space and time, and unpredictable for both parents and offspring. One additional condition is that free mating occurs between individuals developing in one patch and individuals developing in other patches (Charnov \& Bull 1977). Based on the strong dispersal of larvae, the swimming behaviour of atypical males and the environmental heterogeneity in time and space, it is reasonable to conclude that this condition is also fulfilled. Thus, all the conditions for the model proposed by Charnov \& Bull (1977) are validated in the copepod Pachypygus gibber.

ESD allows offspring to choose their sex according to conditions encountered in a way which optimises their fitness. One could thus expect ESD to be common. Although it occurs in various taxonomic groups (e.g. echiurides, nematodes, crustaceans, fish, reptiles, plants), it appears to be less widespread than expected. For example, ESD has not been hitherto determined in copepod species other than Pachypygus gibber. One possible explanation for this fact is that specific investigations on sex-determining mechanisms have been carried out for only a few species, so that ESD may be more common than thought. Nevertheless, disadvantages of ESD compared to GSD might exist. It has been proposed that the time delay in development represents a cost of ESD in species displaying a strong sexual dimorphism, but such constraints have not yet been demonstrated (Korpelainen 1990). Another disadvantage of ESD could be the production of intersexual individuals, whose fitness should be lower than for individuals of 'pure' sex. However, intersexuality is not a constant phenomenon in organisms with ESD. In some organisms intersexual individ- 
uals are rarely produced (e.g. poeciliid fish; Kallman 1984), while in others they occur at a non-negligible frequency in some populations (e.g. the amphipod Gammarus duebeni; cf. Dunn et al. 1990). A third disadvantage of ESD is that between-year fluctuations in the environmental determinant of sex select against ESD (Bull 1981, Bulmer \& Bull 1982). Numerical analyses conducted by Bull \& Bulmer (1989) have shown that this negative impact strongly depends on species longevity. In short-lived species ESD can be maintained only if large sex-specific fitness effects exist, countering the disadvantages of environmental fluctuations. In contrast, in long-lived species even slight sex-specific fitness effects are sufficient to select extreme ESD, despite major between-year fluctations in sex ratio. These results suggest that tests of adaptive ESD are most likely to reach definitive conclusions when conducted for short-lived species.

Surprisingly, the adaptive significance of ESD has been strongly supported in only a few cases. These include the mermithid nematodes (Petersen 1972, 1977, Blackmore \& Charnov 1989), the fish Menidia menidia (cf. Conover 1984, Conover \& Heins 1987), the amphipod Gammarus duebeni (cf. Naylor et al. 1988, McCabe \& Dunn 1997) and now the copepod Pachypygus gibber (cf. Becheikh et al. 1998 and the present study). Other cases of ESD offer only partial support of the Charnov-Bull model, many of them focusing on the first condition of the model (e.g. Zimmerman 1991). However, heterogeneity and unpredictability of the environmental parameters relevant for individual fitness are essential when the adaptiveness of ESD is to be investigated in a species. Analysing all conditions in a single species may be quite complex depending on the species' life cycle and on measurability of the relevant parameters. This could explain why few species with ESD have so far been the subjects of tests analysing all the conditions of the Charnov-Bull model.

Acknowledgements. We thank the SMEL for supplying the material and facilities necessary for this work, and M. Cantou and L. Libicz for their essential contribution in sampling sea squirts in the Thau lagoon. We are very grateful to Prof. D. McKey for providing helpful comments on the manuscript. We thank 2 anonymous reviewers for their useful comments. M.M. was supported by a grant from the French Ministère de l'Education Nationale, de la Recherche et de la Technologie (MENRT).

\section{LITERATURE CITED}

Adams J, Greenwood P, Naylor C (1987) Evolutionary aspects of environmental sex determination. Int $\mathrm{J}$ Invertebr Reprod Dev 11:123-126

Bacci G (1965) Sex determination. Pergamon Press, Oxford Becheikh S (1996) Recherche sur l'écologie et le développe- ment de Pachypygus gibber (Thorell, 1859), copépode Notodelphyidae associé à l'ascidie Ciona intestinalis (L.). Thèse de Doctorat: Biologie des Populations et Ecologie, Université Montpellier II

Becheikh S, Michaud M, Thomas F, Raibaut A, Renaud F (1998) Roles of resource and partner availability in sex determination in a parasitic copepod. Proc R Soc Lond Ser B 265:1153-1156

Blackmore MS, Charnov EL (1989) Adaptive variation in environmental sex determination in a nematode. Am Nat 134:817-823

Bull JJ (1981) Evolution of environmental sex determination from genotypic sex determination. Heredity 47:173-184

Bull JJ (1983) Evolution of sex determining mechanisms. Benjamin/Cummings, Menlo Park, CA

Bull JJ, Bulmer MG (1989) Longevity enhances selection of environmental sex determination. Heredity 63:315-320

Bulmer MG, Bull JJ (1982) Models of polygenic sex determination and sex ratio control. Evolution 36:13-26

Bush AO, Lafferty KD, Lotz JM, Shostak AW (1997) Parasitology meets ecology on its own terms: Margolis et al. revisited. J Parasitol 83:575-583

Charnov EL (1979) The genetical evolution of patterns of sexuality: Darwinian fitness. Am Nat 113:465-480

Charnov EL (1982) The theory of sex allocation. Princeton University Press, Princeton, NJ

Charnov EL, Bull JJ (1977) When is sex environmentally determined? Nature 266:828-830

Conover DO (1984) Adaptive significance of temperaturedependent sex determination in a fish. Am Nat 123(3): 297-313

Conover DO, Heins SW (1987) Adaptive variation in environmental and genetic sex determination in a fish. Nature 326:496-498

Dawson LHJ, Renaud F, Guegan JF, de Meeus T (2000) Experimental evidence of asymmetrical competition between two species of parasitic copepods. Proc R Soc Lond Ser B 267:1973-1978

Dunn AM, Adams J, Smith JE (1990) Intersexes in a shrimp: a possible disadvantage of environmental sex determination. Evolution 44(7):1875-1878

Goudet J (1995) Fstat (Version 1.2) - a computer program to calculate F-statistics. J Heredity 86:485-486

Hipeau-Jacquotte R (1978) Développement post-embryonnaire du copépode ascidicole Notodelphyidae Pachypygus gibber (Thorell, 1859). Crustaceana 34(2):155-194

Hipeau-Jacquotte R (1980) Le développement atypique du copépode ascidicole Notodelphyidae Pachypygus gibber (Thorell, 1859). Arch Zool Exp Gen 121(1):29-47

Hipeau-Jacquotte R, Coste F (1989) Reproductive system of the parasitic copepod Pachypygus gibber: spermatogenesis and spermatophore formation in dimorphic males, and discharge in female tracts. J Crustac Biol 9(2):228-241

Jones KW (1983) Evolution of sex chromosomes. In: Johnson $\mathrm{MH}$ (ed) Development in mammals, Vol 5. Elsevier Science, New York, p 297-320

Kallman KD (1984) A new look at sex determination in poeciliid fishes. In: Turner BJ (ed) Evolutionary genetics of fishes. Plenum Press, New York, p 95-171

Korpelainen H (1990) Sex ratios and conditions required for environmental sex determination in animals. Biol Rev Camb Phil Soc 65:147-184

Margolis L, Esch GW, Holmes JC, Kuris AM, Schad GA (1982) The use of ecological terms in parasitology (report of an ad hoc committee of the American Society of Parasitologists). J Parasitol 68:131-133

McCabe J, Dunn AM (1997) Adaptive significance of environ- 
mental sex determination in an amphipod. J Evol Biol 10:515-527

Michaud M, Thomas F, Becheikh S, Raibaut A, Shykoff JA, Renaud F (1999) Stage dependent decisions in a parasitic copepod practising environmental sex determination. Mar Ecol Prog Ser 185:189-193

Mittwoch U (1971) Sex determination in birds and mammals. Nature 231:432-434

Naylor C, Adams J, Greenwood P (1988) Population dynamics and adaptive sexual strategies in a brackish water crustacean, Gammarus duebeni. J Anim Ecol 57:493-507

Ohno S (1967) Sex chromosomes and sex-linked genes. Springer-Verlag, Berlin

Pasteur N, Pasteur G, Bonhomme F, Catalan J, BrittonDavidian J (1987) Manuel technique de génétique par électrophorèse des protéines. Lavoisier, Paris

Petersen JJ (1972) Factors affecting sex ratios of a mermithid parasite of mosquitoes. J Nematol 4(2):83-87

Editorial responsibility: Otto Kinne (Editor),

Oldendorf/Luhe, Germany
Petersen JJ (1977) Effects of host size and parasite burden on sex ratio in the mosquito parasite Octomyomermis muspratti. J Nematol 9(4):343-346

MathSoft (2000) S-Plus, Guide to statistics, Vol 1. Data Analysis Products Division, MathSoft, Seattle, WA

Trivers RL, Willard DE (1973) Natural selection of parental ability to vary the sex ratio of offspring. Science 179:90-91

Weir BS, Cockerham CC (1984) Estimating F-statistics for the analysis of population structure. Evolution 38:1358-1370

Wright S (1951) The genetical structure of populations. Ann Eugen 15:323-354

Wright S (1965) The interpretation of population structure by F-statistics with special regard to systems of mating. Evolution 19:395-420

Zimmerman JK (1991) Ecological correlates of labile sex expression in the orchid Catasetum viridiflavum. Ecology 72(2):597-608

Submitted: July 17, 2003; Accepted: November 25, 2003

Proofs received from author(s): March 3, 2004 